\title{
THE EFFECTS OF ETHYLENEGLYCOLTETRA-ACETIC ACID ON BACTERICIDAL ACTIVITY OF HUMAN SERUM AGAINST ESCHERICHIA COLI
}

\author{
A. P. Roberts AND RUth Phillips \\ Department of Medicine, Charing Cross Hospital Medical School, London W6 8RF
}

\begin{abstract}
SUMmary. The effects of ethyleneglycoltetra-acetic acid (EGTA) and EGTA + magnesium (MgEGTA) on the viable counts of 10 strains of Escherichia coli 06 have been studied in normal human serum (NHS), heat-inactivated serum (HIS) and in culture media with and without the addition of a $\beta$-lactam antibiotic. The addition of EGTA to NHS largely prevented bactericidal activity against serum-sensitive strains while, in contrast, it reduced the growth of a serum-resistant strain. These apparently paradoxical effects are due to the lower growth rate permitted by the reduced amount of available magnesium in the presence of EGTA.

Experiments with equimolar concentrations of EGTA and magnesium indicated that whilst MgEGTA is a reagent allowing alternative complement-pathway activity, such activity must be determined by comparison with results in HIS + MgEGTA rather than in HIS alone, classical-pathway activity being taken as the difference between the results in NHS and in NHS + MgEGTA.

By these criteria, prompt killing by serum was found to occur via the classical pathway while delayed serum bactericidal activity occurred by the alternative pathway in some strains and by the classical pathway in others.
\end{abstract}

\section{INTRODUCTION}

On the basis of the kinetics of serum bactericidal activity, it has been reported that clinical isolates of Serratia marcescens can be classified as "promptly serum-sensitive" or "delayed serum-sensitive" and that such isolates selectively activate the classical and alternative pathways of complement respectively (Traub and Kleber, 1976). Escherichia coli isolates from urinarytract infections cannot be classified so simply because their response to serum shows a gradation from rapid death to uninhibited growth (Taylor, 1974). It would therefore be of interest to examine the part played by each of the two complement pathways in bactericidal activity against $E$. coli strains differing in serum sensitivity.

Ethyleneglycoltetra-acetic acid (EGTA) has been shown to prevent classical-pathway activation while leaving the alternative pathway functional (Fine 
et al., 1972), but the interpretation of results from serum bactericidal assays in the presence of EGTA presents problems. Bryan (1974) reported that EGTA sensitised a serum-resistant strain of $E$. coli to the bactericidal action of human serum whereas Des Prez et al. (1975), in a study from the same laboratory, found that in the presence of EGTA alternative-pathway activity was suboptimal against four bacterial strains that were "exquisitely" sensitive to normal serum. However, when EGTA was supplemented with magnesium chloride (MgEGTA) the resistant organism was no longer sensitised to serum, and bactericidal activity against the sensitive strains was largely restored.

Because the common urinary $\mathrm{O}$ serogroups of $E$. coli differ in their sensitivity to serum (Taylor, 1974) it was considered important for this initial study to use isolates of the same $\mathrm{O}$ serogroup. Urinary isolates in our laboratory most commonly belong to serogroup O6 (Roberts and Phillips, 1979) and this report concerns the response of 10 strains of $E$. coli 06 to normal human serum and to serum with added EGTA or MgEGTA. The effects of these chelators on bacteria in culture media with and without the addition of a $\beta$-lactam antibiotic are also reported.

\section{MATERIALS AND METHODS}

Bacteria. The 10 strains of $E$. coli $\mathrm{O6}$ were isolated from cultures of suprapubic aspirates of urine. The methods of identification and $\mathrm{O}$ serogrouping have been described previously (Roberts et al., 1975).

Reagents. Solutions of EGTA (Sigma Chemical Company, Poole, Dorset) and MgEGTA, $100 \mathrm{~mm}$ in normal saline, were prepared as described by Fine et al. (1972) and sterilised by filtration through a 0.22- $\mu$ m membrane filter (Millipore type GS).

Preparation and heat inactivation of serum. Blood was obtained from a healthy volunteer on the day of each experiment. After centrifugation of the clotted blood, the serum was taken off and filtered through a $0 \cdot 22-\mu \mathrm{m}$ membrane filter to remove any remaining cells. The serum was added in $1.6-\mathrm{ml}$ portions to three warm $20-\mathrm{ml} \mathrm{screw-capped} \mathrm{bottles} \mathrm{in} \mathrm{a} 56^{\circ} \mathrm{C}$ water bath and to three similar bottles at room temperature. After $30 \mathrm{~min}$ the bottles were removed from the water bath and allowed to cool to room temperature. To each portion of serum was added $0 \cdot 2$ $\mathrm{ml}$ of EGTA, MgEGTA or normal saline $(\mathrm{NaCl}, 0.9 \% \mathrm{w} / \mathrm{v})$.

Culture media. To determine the effects of EGTA and MgEGTA in the absence of complement, experiments were done in which serum was replaced by Nutrient Broth (Oxoid No. 2) or Peptone Water (Oxoid) the latter being diluted to $20 \%(\mathrm{v} / \mathrm{v})$ of its usual concentration with normal saline in an attempt to reduce the bacterial growth rate. In each case the medium was also prepared with the addition of cefuroxime (Glaxo Ltd, Greenford, Middlesex) to give a final concentration of $12.5 \mu \mathrm{g} \mathrm{ml}^{-1}$ after inoculation.

Assay for serum bactericidal activity was a modification of the method of Taylor, Roberts and Gower (1972), without the use of Tris- $\mathrm{HCl}$ buffer and with the same volumes as used by Traub and Kleber (1976). One ml of an 18-h culture in nutrient broth (Oxoid No. 2) was transferred to $9 \mathrm{ml}$ of fresh broth and incubated at $37^{\circ} \mathrm{C}$ with gentle agitation for $90 \mathrm{~min}$. This culture was washed three times in normal saline and resuspended in saline to a concentration of approximately $10^{6}$ organisms $\mathrm{ml}^{-1}$. The serum portions containing chelator or saline were inoculated with $0.2 \mathrm{ml}$ of the bacterial suspension giving a total volume of $2 \mathrm{ml}$ and a final serum concentration of $80 \%(\mathrm{v} / \mathrm{v})$. At the start of each assay and after incubation for 1,2 and $3 \mathrm{~h}$ at $37^{\circ} \mathrm{C}$, viable counts were made by the pour-plate technique. Thus the response of each bacterial strain was assessed in normal human serum + saline (NHS), NHS + EGTA, NHS + MgEGTA, heat-inactivated serum plus saline (HIS), HIS + EGTA, and HIS + MgEGTA on the same day; for each strain, all tests were done three times on different days. 
In the further series of experiments in which serum was replaced by culture media, the assay was done by the same methods.

\section{RESULTS AND DISCUSSION}

The results of all assays involving serum are shown in table 1. For purposes of comparison the viable counts are expressed as a percentage of the inoculum and are the mean of three determinations in each case.

The 10 strains of E. coli $\mathrm{O} 6$ ranged in their response to NHS from strain 439 , of which there were no detectable survivors after $1 \mathrm{~h}$, to strain 401 , which grew to over $1500 \%$ of the inoculum in $3 \mathrm{~h}$. The gradation of the results for the remaining strains between these extremes indicates the artificiality of any simple classification of their response to serum.

After incubation for $3 \mathrm{~h}$ in HIS, all 10 strains showed some increase in viable count but this ranged from $128 \%$ for strain 499 , which appears to have a grewth requirement not supplied by HIS, to over $2500 \%$ for strain 438 . Because strain $\mathbf{4 0 1}$ grew in HIS to a level only slightly less than in NHS it seems that growth of this strain in NHS is completely uninhibited by complement.

NHS and HIS gave remarkably similar results for each of the strains in the presence of EGTA even to the extent of the marked reduction in the viable count of strain 504 after $3 \mathrm{~h}$. This is contrary to the findings of Bryan (1974) and Des Prez et al. (1975) who reported differences between the effects of normal and heat-inactivated serum containing EGTA. However, the washing procedure and specific diluent for the inoculum were not mentioned in the description of their assay and if, as appears likely, the inoculum was suspended in trypticase soy broth this may be the explanation (see below). Nevertheless, the addition of EGTA to NHS might be considered to have resulted in suboptimal bactericidal activity against the eight most sensitive strains in the present study, as with the four very sensitive organisms in the study of Des Prez et al. (1975), and to have sensitised strains 442 and 401 to the bactericidal activity of serum, as with the serum-resistant strain of $E$. coli described by Bryan (1974). The addition of magnesium (MgEGTA) may be regarded as restoring alternative-pathway activity against the five strains most sensitive to NHS, as with the sensitive organisms of Des Prez et al. (1975), and to have restored serum resistance in strain 401 , as with the serum-resistant strain of Bryan (1974). However, the addition of magnesium resulted in higher viable counts of strains 504, 566 and 442 although EGTA had increased the counts of strains 504 and 566 while reducing the counts of strain 442 compared with those in NHS.

In a similar way the addition of EGTA to HIS might be regarded as "sensitising" the strains to the "bactericidal" action of HIS and the addition of magnesium as restoring "resistance" to HIS. This explanation is possibly supported by Bryan's (1974) observation of a similar effect of EGTA and MgEGTA in Hanks's balanced salts solution containing gelatin and lysozyme, but it occurred to us that there might be a simpler explanation for all these phenomena.

Serum bactericidal activity depends on active cell division (Michael and 
TABLE I

The effect of EGTA and MgEGTA on the viable count of Escherichia coli incubated in normal human serum or heat-inactivated serum

\begin{tabular}{|c|c|c|c|c|c|c|c|c|c|c|c|c|c|c|c|c|c|c|}
\hline \multirow{4}{*}{$\begin{array}{c}\text { Strain } \\
\text { no. }\end{array}$} & \multicolumn{16}{|c|}{ Percentage* of inoculum at indicated time in } & & \\
\hline & \multicolumn{9}{|c|}{ normal human serum } & \multicolumn{9}{|c|}{ heat-inactivated serum } \\
\hline & \multicolumn{3}{|c|}{+ saline } & \multicolumn{3}{|c|}{ +EGTA } & \multicolumn{3}{|c|}{+ MgEGTA } & \multicolumn{3}{|c|}{+ saline } & \multicolumn{3}{|c|}{ +EGTA } & \multicolumn{3}{|c|}{+ MgEGTA } \\
\hline & $1 \mathrm{~h}$ & $2 \mathrm{~h}$ & $3 \mathrm{~h}$ & $1 \mathrm{~h}$ & $2 \mathrm{~h}$ & $3 \mathrm{~h}$ & $1 \mathrm{~h}$ & $2 \mathrm{~h}$ & $3 \mathrm{~h}$ & $1 \mathrm{~h}$ & $2 \mathrm{~h}$ & $3 \mathrm{~h}$ & $1 \mathrm{~h}$ & $2 \mathrm{~h}$ & $3 \mathrm{~h}$ & $1 \mathrm{~h}$ & $2 \mathrm{~h}$ & $3 \mathrm{~h}$ \\
\hline $\begin{array}{l}439 \\
294 \\
499 \\
438 \\
502 \\
304 \\
504 \\
566 \\
442 \\
401\end{array}$ & $\begin{array}{r}<1 \\
4 \\
28 \\
58 \\
85 \\
106 \\
102 \\
149 \\
188 \\
210\end{array}$ & $\begin{array}{r}<1 \\
<1 \\
2 \\
23 \\
45 \\
<1 \\
43 \\
169 \\
197 \\
754\end{array}$ & $\begin{array}{r}<1 \\
<1 \\
<1 \\
4 \\
7 \\
<1 \\
<1 \\
29 \\
80 \\
1545\end{array}$ & $\begin{array}{r}93 \\
84 \\
88 \\
97 \\
105 \\
103 \\
81 \\
103 \\
88 \\
106\end{array}$ & $\begin{array}{r}89 \\
85 \\
75 \\
201 \\
118 \\
170 \\
64 \\
151 \\
89 \\
245\end{array}$ & $\begin{array}{r}91 \\
86 \\
67 \\
260 \\
147 \\
267 \\
37 \\
145 \\
57 \\
283\end{array}$ & $\begin{array}{r}73 \\
106 \\
75 \\
134 \\
136 \\
161 \\
152 \\
169 \\
175 \\
200\end{array}$ & $\begin{array}{r}5 \\
5 \\
1 \\
22 \\
56 \\
209 \\
137 \\
333 \\
240 \\
717\end{array}$ & $\begin{array}{r}<1 \\
<1 \\
<1 \\
16 \\
22 \\
165 \\
82 \\
244 \\
210 \\
1675\end{array}$ & $\begin{array}{r}132 \\
114 \\
97 \\
131 \\
163 \\
177 \\
113 \\
150 \\
156 \\
126\end{array}$ & $\begin{array}{r}480 \\
303 \\
99 \\
728 \\
530 \\
684 \\
482 \\
633 \\
646 \\
730\end{array}$ & $\begin{array}{r}986 \\
687 \\
128 \\
2553 \\
1630 \\
1447 \\
840 \\
2133 \\
1914 \\
1358\end{array}$ & $\begin{array}{r}88 \\
101 \\
91 \\
106 \\
102 \\
178 \\
94 \\
105 \\
106 \\
107\end{array}$ & $\begin{array}{r}87 \\
100 \\
87 \\
163 \\
134 \\
212 \\
89 \\
123 \\
100 \\
267\end{array}$ & $\begin{array}{r}95 \\
89 \\
78 \\
162 \\
176 \\
293 \\
35 \\
155 \\
75 \\
302\end{array}$ & $\begin{array}{r}126 \\
121 \\
93 \\
111 \\
93 \\
139 \\
108 \\
129 \\
91 \\
111\end{array}$ & $\begin{array}{r}346 \\
304 \\
90 \\
412 \\
192 \\
377 \\
292 \\
290 \\
168 \\
347\end{array}$ & $\begin{array}{r}611 \\
502 \\
96 \\
404 \\
339 \\
481 \\
418 \\
275 \\
274 \\
406\end{array}$ \\
\hline
\end{tabular}

EGTA = ethyleneglycoltetra-acetic acid; MgEGTA = EGTA + magnesium.

* Mean of three determinations. 
Braun, 1959; Waisbren and Brown, 1964). If the addition of EGTA to serum reduced the concentration of magnesium available for the bacteria to a level at which their growth rate was restricted (Webb, 1968), sensitive strains could be protected from the bactericidal action of serum in a manner analogous to the protective effect of bacteriostatic agents in the presence of $\beta$-lactam antibiotics. Similarly, serum-resistant strains in normal serum and all strains in heat-inactivated serum would grow less well in the presence of EGTA. The differing ability of strains to tolerate a low concentration of magnesium, or to compete with EGTA for magnesium, may explain the fall in viable count of some strains in HIS + EGTA while others were able to increase very slowly. As a test of this hypothesis it was necessary to study the effects of EGTA and MgEGTA in systems devoid of serum.

Nutrient broth with and without the addition of a $\beta$-lactam antibiotic were used as substitutes for normal and heat-inactivated serum respectively. Cefuroxime, a $\beta$-lactamase-stable cephalosporin (O'Callaghan et al., 1976) was chosen as the antibiotic because several of the strains were resistant to the more common $\beta$-lactam antibiotics such as ampicillin and cephalexin. Three strains of differing sensitivity to NHS were selected for study.

Although the three strains differed in sensitivity to serum, each could be regarded as having delayed sensitivity to nutrient broth containing cefuroxime (table II). The addition of EGTA had a small protective effect for strains 499 and 401 while the addition of magnesium restored most of the bactericidal activity against these two strains. These effects were not nearly so marked as with NHS but the results for nutrient broth without antibiotic may account for this, in that the growth was far greater than in HIS and, although the addition of EGTA reduced the growth very significantly, it was still of the same order as in HIS alone. However, as with HIS, the addition of magnesium partially restored the rate of growth. The fact that the restoration was only partial indicates that EGTA chelates other divalent cations important for bacterial growth. It is also clear from these results that if serum is enriched by suspending the inoculum in culture medium the effects of the chelator are likely to be modified (see above).

In an attempt to reproduce more closely the growth rate found in HIS, a series of experiments was done in which nutrient broth was replaced by peptone water diluted to $20 \%$ of its usual concentration with normal saline. Table III shows that in this objective we were successful only in the case of strain 504. However, it is of interest that in this nutritionally poor medium EGTA was bactericidal for all three strains, and that this effect was again partially overcome by the addition of magnesium. For two of the three strains, cefuroxime was markedly less effective than in nutrient broth (cf. table II) but surprisingly the addition of EGTA to the peptone water containing cefuroxime resulted in significantly less killing than with either cefuroxime or EGTA alone, each compound apparently affording protection against the effect of the other. The addition of magnesium largely restored the bactericidal activity, presumably of cefuroxime because MgEGTA in the absence of antibiotic caused little reduction in the viable count. 
TABLE II

The effect of EGTA and MgEGTA on the viable count of Escherichia coli incubated in nutrient broth with or without the addition of cefuroxime

\begin{tabular}{|c|c|c|c|c|c|c|c|c|c|c|c|c|c|c|c|c|c|c|}
\hline \multirow{4}{*}{$\begin{array}{c}\text { Strain } \\
\text { no. }\end{array}$} & \multicolumn{15}{|c|}{ Percentage ${ }^{*}$ of inoculum at indicated time in } & & & \\
\hline & \multicolumn{9}{|c|}{ nutrient broth containing cefuroxime } & \multicolumn{9}{|c|}{ nutrient broth } \\
\hline & \multicolumn{3}{|c|}{ + saline } & \multicolumn{3}{|c|}{ +EGTA } & \multicolumn{3}{|c|}{+ MgEGTA } & \multicolumn{3}{|c|}{+ saline } & \multicolumn{3}{|c|}{ +EGTA } & \multicolumn{3}{|c|}{+ MgEGTA } \\
\hline & $1 \mathrm{~h}$ & $2 \mathrm{~h}$ & $3 \mathbf{h}$ & $1 \mathrm{~h}$ & $2 \mathrm{~h}$ & $3 \mathrm{~h}$ & $1 \mathrm{~h}$ & $2 \mathrm{~h}$ & $3 \mathrm{~h}$ & $1 \mathrm{~h}$ & $2 \mathrm{~h}$ & $3 \mathrm{~h}$ & $1 \mathrm{~h}$ & $2 \mathrm{~h}$ & $3 \mathrm{~h}$ & $1 \mathrm{~h}$ & $2 \mathrm{~h}$ & $3 \mathrm{~h}$ \\
\hline $\begin{array}{l}499 \\
504 \\
401\end{array}$ & $\begin{array}{r}129 \\
84 \\
99\end{array}$ & $\begin{array}{l}29 \\
23 \\
11\end{array}$ & $\begin{array}{l}<1 \\
<1 \\
<1\end{array}$ & $\begin{array}{r}113 \\
89 \\
94\end{array}$ & $\begin{array}{r}117 \\
51 \\
55\end{array}$ & $\begin{array}{r}36 \\
2 \\
10\end{array}$ & $\begin{array}{r}168 \\
92 \\
88\end{array}$ & $\begin{array}{l}77 \\
43 \\
22\end{array}$ & $\begin{array}{l}1 \\
2 \\
1\end{array}$ & $\begin{array}{l}281 \\
218 \\
464\end{array}$ & $\begin{array}{l}1397 \\
1592 \\
1923\end{array}$ & $\begin{array}{l}18543 \\
14720 \\
24452\end{array}$ & $\begin{array}{l}127 \\
123 \\
166\end{array}$ & $\begin{array}{l}461 \\
270 \\
239\end{array}$ & $\begin{array}{r}1593 \\
1239 \\
504\end{array}$ & $\begin{array}{l}258 \\
230 \\
244\end{array}$ & $\begin{array}{l}779 \\
810 \\
956\end{array}$ & $\begin{array}{l}7632 \\
7931 \\
8978\end{array}$ \\
\hline
\end{tabular}

Footnotes as in table I. 


\section{TABle III}

The effect of EGTA and MgEGTA on the viable count of Escherichia coli incubated in $20 \%$ peptone water with or without the addition of cefuroxime

\begin{tabular}{|c|c|c|c|c|c|c|c|c|c|c|c|c|c|c|c|c|c|c|}
\hline \multirow{4}{*}{$\begin{array}{c}\text { Strain } \\
\text { no. }\end{array}$} & \multicolumn{18}{|c|}{ Percentage* of inoculum at indicated time in } \\
\hline & \multicolumn{9}{|c|}{$20 \%$ peptone water containing cefuroxime } & \multicolumn{9}{|c|}{$20 \%$ peptone water } \\
\hline & \multicolumn{3}{|c|}{ + saline } & \multicolumn{3}{|c|}{ +EGTA } & \multicolumn{3}{|c|}{+ MgEGTA } & \multicolumn{3}{|c|}{ + saline } & \multicolumn{3}{|c|}{ +EGTA } & \multicolumn{3}{|c|}{+ MgEGTA } \\
\hline & $1 \mathrm{~h}$ & $2 \mathrm{~h}$ & $3 \mathrm{~h}$ & $1 \mathrm{~h}$ & $2 \mathrm{~h}$ & $3 \mathrm{~h}$ & $1 \mathrm{~h}$ & $2 \mathrm{~h}$ & $3 \mathrm{~h}$ & $1 \mathrm{~h}$ & $2 \mathrm{~h}$ & $3 \mathrm{~h}$ & $1 \mathrm{~h}$ & $2 \mathrm{~h}$ & $3 \mathrm{~h}$ & $1 \mathrm{~h}$ & $2 \mathrm{~h}$ & $3 \mathrm{~h}$ \\
\hline $\begin{array}{l}499 \\
504 \\
401\end{array}$ & $\begin{array}{l}77 \\
91 \\
81\end{array}$ & $\begin{array}{r}9 \\
72 \\
12\end{array}$ & $\begin{array}{l}<1 \\
37 \\
10\end{array}$ & $\begin{array}{r}94 \\
96 \\
115\end{array}$ & $\begin{array}{l}89 \\
70 \\
75\end{array}$ & $\begin{array}{l}87 \\
57 \\
36\end{array}$ & $\begin{array}{l}76 \\
87 \\
64\end{array}$ & $\begin{array}{l}67 \\
77 \\
26\end{array}$ & $\begin{array}{r}9 \\
40 \\
4\end{array}$ & $\begin{array}{l}482 \\
140 \\
313\end{array}$ & $\begin{array}{r}2011 \\
217 \\
1864\end{array}$ & $\begin{array}{r}10989 \\
650 \\
16505\end{array}$ & $\begin{array}{r}108 \\
50 \\
61\end{array}$ & $\begin{array}{r}57 \\
29 \\
8\end{array}$ & $\begin{array}{r}13 \\
14 \\
4\end{array}$ & $\begin{array}{l}166 \\
130 \\
169\end{array}$ & $\begin{array}{r}155 \\
92 \\
366\end{array}$ & $\begin{array}{r}132 \\
75 \\
286\end{array}$ \\
\hline
\end{tabular}

Footnotes as in table I. 
Although neither of these two series of experiments exactly reproduced the results obtained with serum, they support our contention that the effects of EGTA on serum-sensitive and serum-resistant strains are the same. By restricting the availability of magnesium, and possibly of other divalent cations, EGTA slows the rate of bacterial growth and in some cases may even cause a fall in viable count. In this way, serum-resistant strains will grow more slowly, or even be killed, in serum containing EGTA whereas serum-sensitive strains will be killed more slowly or not at all because of the dependence of the bactericidal system on active bacterial cell division. The apparently paradoxical results obtained with sensitive and resistant organisms in serum containing EGTA thus have a single explanation directly involving the bacterium rather than two indirect and contradictory explanations involving complement.

We agree with the conclusion of Des Prez et al. (1975) that MgEGTA can be used as a reagent permitting alternative pathway activity if caution is exercised in the interpretation of the results. It is particularly important to note that the action of the chelator on complement activity can be distinguished from its influence on growth only by comparing its effects in sera containing and not containing active complement. Thus the result in NHS + MgEGTA cannot be taken as a measure of alternative-pathway bactericidal activity except by comparison with that obtained in HIS + MgEGTA.

With the difference between NHS and NHS + EGTA as a measure of classical-pathway activity, it is clear from the results shown in table I that the prompt killing of strains 439 and 294 is due to classical-pathway activation, as with promptly serum-sensitive strains of $S$. marcescens (Traub and Kleber, 1976) and, further, that delayed killing occurs via the alternative pathway. The delayed serum sensitivity of strains 499,438 and 502 was due to alternative-pathway activity because the addition of MgEGTA to NHS had little effect and the results with HIS +EGTA were markedly different. These results are again similar to those obtained with strains of $S$. marcescens with delayed serum sensitivity. In contrast, however, the delayed killing of strains $304,504,566$ and 442 in NHS was largely due to classical-pathway activity because the addition of MgEGTA resulted in even further delay while very little alternative-pathway activity was apparent from the comparison of these results with those obtained in HIS + MgEGTA. The serum-resistant strain, 401, grew to a similar extent in NHS, NHS + MgEGTA and HIS, suggesting that growth in NHS was completely uninhibited. However, the poor growth in HIS + MgEDTA indicates that the situation might be more complex and that heat inactivation of serum may affect its nutritional properties and create a greater dependence on divalent cations.

Previous work has shown that strains of $S$. marcescens may be killed promptly by serum via activation of the classical complement pathway and, after a delay, by alternative-pathway activation (Traub and Kleber, 1976). The present study shows this to be true for some strains of $E$. coli $\mathrm{O} 6$ but that others may show delayed killing by the classical pathway. It will be necessary to determine whether these and possibly other patterns of response to serum 
occur in other $O$ serogroups of $E$. coli and to take account of them in attempts to determine the basis of complete resistance to serum bactericidal activity.

\section{REFERENCES}

BRYAN, C. S. 1974. Sensitization of $E$. coli to the serum bactericidal system and to lysozyme by ethyleneglycoltetraacetic acid. Proc. Soc. exp. Biol. Med., 145, 1431.

Des Prez, R. M., Bryan, C. S., Hawiger, J. AND Colley, D. G. 1975. Function of the classical and alternate pathways of human complement in serum treated with ethylene glycol tetraacetic acid and $\mathrm{MgCl}_{2}$-ethylene glycol tetraacetic acid. Infect. Immun., 11, 1235 .

Fine, D. P., Marney, S. R., Colley, D. G., Sergent, J. S. and Des Prez, R. M. 1972. C3 shunt activation in human serum chelated with EGTA. J. Immun., 109, 807.

Michael, J. G. AND BRAUN, W. 1959. Modification of bactericidal effects of human serum. Proc. Soc. exp. Biol. Med., 102, 486.

O'Callaghan, C. H., Sykes, R. B., Ryan, D. M., Foord, R. D. and Muggleton, P. W. 1976. Cefuroxime-a new cephalosporin antibiotic. J. Antibiot., Tokyo, 29, 29.

Roberts, A. P., Linton, J. D., Waterman, A. M., Gower, P. E. and Koutsaimanis, K. G. 1975. Urinary and faecal Escherichia coli O-serogroups in symptomatic urinary-tract infection and asymptomatic bacteriuria. J. med. Microbiol., 8, 311 .

RoBer TS, A. P. AND PHILlIPS, R. 1979. Bacteria causing symptomatic urinary tract infection or asymptomatic bacteriuria. J. clin. Path., 32, 492.

TAYLOR, P. W. 1974. Sensitivity of some smooth strains of Escherichia coli to the bactericidal action of normal human serum. J. clin. Path., $27,626$.

TAYLOR, P. W., ROBERTS, A. P. AND GoWER, P. E. 1972. Evaluation of a technique for the estimation of serum bactericidal activity against gram-negative organisms. Med. lab. Technol., 29, 272.

TRAUB, W. H. AND KLEBER, I. 1976. Selective activation of classical and alternative pathways of human complement by "promptly serum-sensitive" and "delayed serum-sensitive" strains of Serratia marcescens. Infect. Immun., 13, 1343.

WAISBREN, B.A. AND BROWN, I. 1964. Effect of wide spectrum antibiotics on bactericidal activity of human serum in vitro and in vivo. Am. J. med. Sci., 248, 56.

WEBB, M. 1968. The influence of certain trace metals on bacterial growth and magnesium utilization. J. gen. Microbiol., 51, 325. 